\title{
Michał Zaremba
}

Uniwersytet Łódzki

e-mail: michal.zaremba@uni.lodz.pl

ORCID: 0000-0001-9525-9100

\section{DZIALALNOŚĆ INWESTYCYJNA \\ AZJATYCKIEGO BANKU INWESTYCJI INFRASTRUKTURALNYCH}

\section{INVESTMENT ACTIVITY OF ASIAN INFRASTRUCTURE INVESTMENT BANK}

DOI: $10.15611 / \mathrm{e} 21.2018 .4 .03$

JEL Classification: F35, F53, F55

Streszczenie: Działający od 2016 roku Azjatycki Bank Inwestycji Infrastrukturalnych (Asian Infrastructure Investment Bank - AIIB) od początku wzbudza dyskusje zarówno wśród badaczy, jak i decydentów. O potencjale instytucji świadczy fakt, że w ciągu dwóch lat swego funkcjonowania stała się prawdziwie międzynarodową instytucją, skupiającą ponad połowę członków UE, znaczną część krajów OECD i coraz liczniejsze grono krajów rozwijających się. Ponadto trzy najważniejsze agencje ratingowe - Moody's, S\&P oraz Fitch - przyznały bankowi najwyższy rating. Z jednej strony podkreśla się, że AIIB może zapewnić wsparcie kapitałowe krajom rozwijającym się, z drugiej pojawiają się obawy co do dominacji Chin, które mogą wykorzystać bank do realizacji własnych interesów politycznych i gospodarczych. Artykuł jest próbą analizy działalności inwestycyjnej Azjatyckiego Banku Inwestycji Infrastrukturalnych od momentu jego powstania.

Słowa kluczowe: AIIB, gospodarka chińska, Chiny, instytucje międzynarodowe, instytucje na rzecz rozwoju.

Summary: The Asian Infrastructure Investment Bank (AIIB) operating since 2016 from the beginning has provoked discussions among researchers and decision makers. Within two years of its operation activity it has become a truly international institution, gathering more than half of EU members, a significant part of OECD countries and an increasing number of developing countries. In addition, three major rating agencies - Moody's, S\&P and Fitch awarded the bank the highest rating. On the one hand, there are indications that AIIB can provide capital support to developing countries, on the other, there are concerns about Chinese domination as it might be used to pursue its own political and economic interests. The purpose of the paper is to analyze the investment activities of the Asian Infrastructure Investment Bank since its creation.

Keywords: AIIB, Chinese economy, China, international institutions, developmental institutions. 


\section{Wstęp}

Mimo niechęci Stanów Zjednoczonych i Japonii Azjatycki Bank Inwestycji Infrastrukturalnych (AIIB - Asian Infrastructure Investment Bank) w ciągu dwóch lat swego istnienia stał się prawdziwie międzynarodową instytucją, skupiającą kraje UE, znaczną część krajów OECD i dużą liczbę krajów rozwijających się. Brak doświadczenia AIIB nie uniemożliwił młodej instytucji uzyskania najwyższego ratingu kredytowego przyznanego przez trzy główne agencje ratingowe - Moody's, S\&P i Fitch. Oznacza to, że młoda instytucja ma taką samą ocenę jak Bank Światowy.

Od momentu swojego powstania AIIB wywołuje spore emocje. $Z$ jednej strony jego zwolennicy podkreślają, że AIIB może zapewnić zasoby kapitałowe potrzebne do sfinansowania ogromnej luki inwestycyjnej w Azji, której wysokość do 2030 roku ma wynieść 26 bilionów USD [ADB 2018]. Z drugiej strony część badaczy i analityków jest zaniepokojona faktyczną dominacją Chin, które mogą wykorzystać AIIB do realizacji własnych strategicznych interesów. Ponadto istnieją obawy, że AIIB może nie przestrzegać odpowiednich standardów zarządzania oraz odpowiedzialności społecznej i środowiskowej.

Mimo tych uwag nie jest jeszcze możliwa, przede wszystkim ze względu na krótki okres działalności operacyjnej, jednoznaczna ocena dotychczasowej polityki banku, również w zakresie jego niezależności względem Chin. Niemniej można już analizować dotychczasową działalność inwestycyjną, która najlepiej pokazuje, jakimi drogami podąża i jakie cele ma AIIB.

Artykuł jest próbą analizy działalności inwestycyjnej Azjatyckiego Banku Inwestycji Infrastrukturalnych od momentu jego powstania. Osiągnięciu celu ma służyć analiza literatury oraz analiza z wykorzystaniem miar statystyki opisowej.

\section{Azjatycki Bank Inwestycji Infrastrukturalnych - wybrane aspekty powstania}

Ład światowy, opierający się na politycznej, gospodarczej i kulturowej dominacji krajów Zachodu, od lat jest coraz silniej kontestowany przez kraje rozwijające się. Najbardziej zainteresowane gruntownymi zmianami są Chiny, wyrastające na globalną potęgę nie tylko gospodarczą, ale również polityczną. Wyrazem ambicji mocarstwowych Chin są przede wszystkim inicjowane z rozmachem projekty międzynarodowe: inicjatywa Jednej Drogi, Jednego Pasa, wcześniejsza współpraca w ramach grupy BRICS czy powołanie Nowego Banku Rozwoju [Zaremba 2017, s. 198-206]. Na gruncie ideologicznym promuje się ideę renesansu narodu chińskiego oraz intensywnie rozwija się sieć Instytutów Konfucjusza na całym świecie, promujących kulturę, historię i język chiński. $Z$ drugiej strony coraz aktywniejsze stają się inne kraje rozwijające się: Indie, już teraz przejawiające ogromne ambicje mocarstwowe, Japonia, Indonezja, RPA czy Brazylia. Wszystko to wskazuje, że stary 
ład światowy, powstały po II wojnie światowej, załamuje się, a świat zmierza w kierunku wielobiegunowości (por. [Czaputowicz 2007, s. 187]).

W tym kontekście istotny jest problem architektury międzynarodowych instytucji finansowych, w szczególności Międzynarodowego Funduszu Walutowego i Banku Światowego. Kontrowersje wynikają przede wszystkim z wysokiej dysproporcji w liczbie głosów w stosunku do potencjału gospodarczego, politycznego i ludnościowego krajów rozwijających się. Udział głosów krajów BRICS w Międzynarodowym Banku Odbudowy i Rozwoju wynosi 13,1\%, natomiast udział w światowym, nominalnym PKB to $23,1 \%$. Chiny posiadają jednie $4,78 \%$ głosów, ponad trzykrotnie mniej niż USA $(15,98 \%)$ czy Japonia, posiadająca ich 7,40\%, mimo że gospodarka tych państw w wymiarze nominalnym jest już największa na świecie (por. rys. 1).



Rys. 1. Siła głosów w Międzynarodowym Funduszu Walutowym (IMF), Banku Światowym i Azjatyckim Banku Rozwoju (ADB) USA, Japonii i Chin

Źródło: [International Bank for Reconstruction...]

Utworzenie Azjatyckiego Banku Inwestycji Infrastrukturalnych nie tylko odzwierciedla rosnącą siłę gospodarczą i polityczną Chin czy też szeroko pojętych krajów rozwijających się, ale również jest wynikiem frustracji związanych z nieudanymi próbami zwiększenia reprezentacji krajów rozwijających się w istniejących międzynarodowych instytucjach finansowych. Aktualna sytuacja może być postrzegana jako forma faktycznego monopolu zachodnich krajów wysoko rozwiniętych i ich paternalistycznego podejścia do polityki światowej (por. tab. 1).

Kontrowersje wzbudzają również efektywność i adekwatność rozwiązań w zakresie polityki gospodarczej, narzucanych przez te instytucje. Negatywne skutki liberalizacji i otwierania się gospodarek oraz brak pogłębionej analizy skutkowały 
Tabela 1. Porównanie wybranych charakterystyk Banku Światowego, Azjatyckiego Banku Rozwoju (ADB) i AIIB w momencie jego powstania

\begin{tabular}{|l|l|l|l|}
\hline Zmienna & \multicolumn{1}{|c|}{ Instytucja } & \multicolumn{1}{c|}{$\begin{array}{c}\text { Azjatycki Bank } \\
\text { Rozwoju }\end{array}$} & \multicolumn{1}{c|}{ AIIB } \\
\hline Baza kapitałowa & 252,8 mld USD & 142,6 mld USD & 100 mld USD \\
\hline Rating & AAA & AAA & AAA \\
\hline Liczba pracowników & powyżej 10,000 & 3,092 & 100 \\
\hline Liczba członków & 188 & 67 & 80 \\
\hline
\end{tabular}

Źródło: [Liu, Umehara2017, s. 9].

m.in. wzrostem nierówności dochodowych, powstawaniem enklaw bogactwa, wyzyskiem w fabrykach należących do korporacji transnarodowych oraz utrzymującymi się skorumpowanymi i słabymi rządami. Problemy nie zostały rozwiązane, a często się pogłębiały. Rzeczywistość gospodarcza krajów rozwijających się okazała się bardziej skomplikowana, niż wynikało to z rozważań akademickich i zaleceń formułowanych w międzynarodowych instytucjach gospodarczych [Piasecki 2008, s. 230-231].

W tym kontekście budowa nowej międzynarodowej instytucji finansowej, jaką jest AIIB, wydaje się reakcją na obecną sytuację. Fakt, że od utworzenia ostatniego dużego wielostronnego banku rozwoju - Europejskiego Banku Odbudowy i Rozwoju w 1991 - minęło prawie trzydzieści lat, oraz fakt, że nowy bank jest wspierany przez Chiny (a nie przez tradycyjne zachodnie mocarstwa lub Japonię), sygnalizuje fundamentalną zmianę w światowej polityce i gospodarce. Wielu sojuszników Stanów Zjednoczonych, w tym Australia, Korea Południowa, Wielka Brytania, Niemcy i Francja, zdecydowało się dołączyć do AIIB, mimo daleko posuniętej wstrzemięźliwości USA.

Chociaż nie ma bezpośrednich dowodów na to, że Chiny próbują kształtować AIIB tak, by realizował ich własną politykę, błędem byłoby ignorowanie czynników krajowych, które przyczyniły się do powstania banku. Co najmniej dwa aspekty chińskiej strategii gospodarczej są istotne w kontekście AIIB. Po pierwsze, przeinwestowanie pozostawiło po sobie spuściznę zapasów, nadwyżek zdolności produkcyjnych i miast-widm w chińskim krajobrazie. Jednocześnie chińskie rezerwy walutowe są największe na świecie. Oczywistym rozwiązaniem wydaje się ustanowienie instytucji, która umożliwi upłynnienie rezerw i zapasów tak, by ta gospodarka wciąż mogła rozwijać się relatywnie szybko (por. [De Jonge 2017, s. 1061-1084]).

Drugim aspektem jest rywalizacja $\mathrm{w}$ rejonie Azji oraz zmiany w światowej polityce. $\mathrm{Z}$ jednej strony dobrowolne, formalne ustanowienie wielostronnej instytucji międzynarodowej wydaje się ograniczać swobodę działania Chin. Jednak wielopłaszczyznowe i wielostronne decyzje dotyczące finansowania mogą również uchronić Chiny przed napięciami politycznymi. Kraje w Azji mogą bardziej akceptować finansowanie pochodzące $\mathrm{z}$ instytucji wielostronnej, nawet jeśli są kierowane przez 
Chiny, niż bezpośrednio z Chin. W tym kontekście AIIB rozszerza możliwości Chin w realizacji ich polityki. AIIB może być narzędziem, przez które zdolności inwestycyjne Chin mogą zostać przekierowane z krajowej gospodarki na zewnątrz.

Otwartym pytaniem jest to, na ile AIIB będzie bankiem rozwoju, porównywalnym do innych tego typu instytucji, a na ile międzynarodową instytucją chińską w ten lub inny sposób realizującą chińskie interesy. Słowo „rozwój” nie występuje w nazwie banku, a artykuły statutu (Articles of Agreement) stanowią, że jego celem jest wspieranie inwestycji w regionie i uwzględnianie potrzeb mniej rozwiniętych członków [AIIBa]. Nie jest celem, jak w przypadku tradycyjnych banków rozwoju, ograniczenie ubóstwa. Jeżeli AIIB ma ambicje bycia prawdziwie międzynarodową instytucją wielostronną, finansowane przez nią projekty nie powinny być wybierane pod kątem interesów Chin, lecz w interesie krajów pożyczających. Największym ryzykiem dla banku jest chińska tendencja do kontrolowania znaczących instytucji powiązanych z Chinami. W porównaniu z Azjatyckim Bankiem Rozwoju i Bankiem Światowym Chiny mają silniejsze prawo weta w stosunku do podejmowanych decyzji niż najważniejsi członkowie w innych instytucjach międzynarodowych.

Rozważania te sugerują, że utworzenie AIIB jest ważnym etapem w strukturze globalnego zarządzania i odzwierciedla kluczowe zmiany w ładzie światowym. Jednym z kluczowych celów, jakie postawili sobie twórcy banku, jest ustanowienie nowych ustaleń organizacyjnych dających odpowiedni głos krajom wschodzącym i rozwijającym się oraz bardziej skutecznym i sprawiedliwym praktykom kredytowym $\mathrm{w}$ porównaniu $\mathrm{z}$ obecnie funkcjonującymi instytucjami.

\section{Powstanie Azjatyckiego Banku Inwestycji Infrastrukturalnych jako element chińskiej ekspansji}

Po raz pierwszy zapowiedź utworzenia nowej instytucji międzynarodowej pojawiła się w 2013 r. w Dżakarcie, podczas wizyty prezydenta Xi Jinpinga, gdy Chiny zobowiązały się udzielić pożyczek na rozwój infrastruktury w krajach Azji Południowo-Wschodniej. Zgodnie z deklaracjami podkreślono, że AIIB będzie współpracować $\mathrm{z}$ istniejącymi wielostronnymi bankami rozwoju. Pierwsze wielostronne spotkanie konsultacyjne w sprawie utworzenia banku odbyło się 24 stycznia 2014 r. z udziałem ponad dziesięciu potencjalnych członków z Azji. Warto zauważyć, że choć do pierwszej tury rozmów w sprawie AIIB nie zostały włączone Indie, stały się one ostatecznie sygnatariuszami protokołu ustaleń powołujących AIIB [Callaghan, Hubbard 2016, s. 121]. Chiny dostarczyły kapitału początkowego w wysokości 50 miliardów dolarów, przy czym ich udział w głosowaniu wynosi około 28,5\% [Etzioni 2016, s. 174].

AIIB zostało założone przez 57 członków-założycieli - 37 członków regionalnych i 20 spoza regionu. 23 marca 2017 r. Zarząd zatwierdził 13 dodatkowych wniosków o członkostwo pięciu kandydatów regionalnych (Afganistan, Armenia, Fidżi, Hongkong, Chiny i Timor-Leste) i ośmiu spoza regionu (Belgia, Kanada, Etiopia, 
Węgry, Irlandia, Peru, Republika Sudanu i Wenezuela), co oznaczało wzrost liczby członków do 70. Pięciu członków, którzy wnieśli największą ilość kapitału po Chinach, to Indie, Rosja, Korea Południowa, Australia i Indonezja [AIIB 2017; AIIB 2018]. Członkami nie są, przede wszystkim z przyczyn politycznych, Stany Zjednoczone, Japonia i Tajwan.

W momencie powstanie banku Chiny zostały największym udziałowcem $(30,34 \%)$, zaraz za nimi Indie z wkładem 8,37 miliarda dolarów. Na trzecim miejscu znalazła się Rosja z wkładem wynoszącym 6,53 miliarda dolarów, a na czwartym Korea Południowa z wkładem o wartości 3,74 miliarda dolarów. Na podstawie formuły głosowania, która jest skorelowana $\mathrm{z}$ wkładem kapitałowym każdego członka i wielkością jego gospodarki, Chiny otrzymały 26,06\% głosów, Indie - 7,5\%, Rosja $-5,92 \%$, Korea Południowa - 3,5\% [Chin 2016, s. 13]. Zgodnie z art. 28 ust. 2 decyzje dotyczące struktury, członkostwa, podwyższenia kapitału i innych istotnych kwestii wymagają większości wynoszącej nie mniej niż trzy czwarte całkowitej liczby głosów przysługujących członkom, co daje Chinom de facto prawo weta [AIIBa]. Jest to rozwiązanie podobne do amerykańskiego faktycznego prawa weta wobec decyzji Banku Światowego, które to prawo wymaga 85\% większości. Decyzje w AIIB, w których Chiny mają prawo weta, obejmują: zwiększenie kapitału banku, zwiększenie subskrypcji kapitałowej członka, rozszerzenie działalności banku, zmianę wielkości rady dyrektorów, zmianę struktury, powoływania lub odwoływania prezesa banku, zawieszenia członka, zakończenia działalności banku i sprzedaży jego aktywów, zmiany artykułów statutu.

Statut AIIB (Articles of Agreement) wszedł w życie 25 grudnia 2015 r. Na inauguracyjnym posiedzeniu zarządu w dniach 16-17 stycznia 2016 r. prezes banku i dwunastoosobowa rada dyrektorów zostali formalnie wybrani i zatwierdzono kluczowe dokumenty. Od kwietnia do maja w 2016 r. AIIB podpisał umowę ramową o współpracy i współfinansowaniu z Bankiem Światowym i porozumienia z Azjatyckim Bankiem Rozwoju, EBOR i Europejskim Bankiem Inwestycyjnym. Umowa między AIIB i Bankiem Światowym określa parametry dla projektów inwestycyjnych współfinansowanych przez obie instytucje, torując drogę wspólnym projektom transportowym, wodnym i energetycznym w Azji. Umowa przewiduje, że Bank Światowy będzie przygotowywał i nadzorował współfinansowane projekty zgodnie ze swoimi procedurami i standardami [World Bank 2016]. Stosunki z EIB również są szczególnie istotne ze względu na specjalistyczną wiedzę EIB oraz wiodącą rolę na rynku obligacji ekologicznych i finansowania inwestycji ekologicznych [EIB 2018].

Biorąc pod uwagę wysoki poziom zapotrzebowania na infrastrukturę w południowo-wschodniej Azji, uznaje się, że państwa ASEAN będą głównymi beneficjentami finansowania z AIIB. Ze względów politycznych ogromne znaczenie będzie miał Pakistan, przez który możliwe będzie wywieranie wpływu na Indie. W kwietniu 2015 r. Prezydent Xi i premier Nawaz Sharif uzgodnili plan finansowania infrastruktury o wartości 46 mld dolarów, w dużej mierze przeznaczony na budowę 3000-ki- 
lometrowego korytarza gospodarczego Chiny-Pakistan, łączącego chiński Kaszgar z Gwadarem w Pakistanie oraz na port głębinowy na Morzu Arabskim, budowany i kontrolowany przez Chiny na podstawie 40-letniej umowy najmu. Plan finansowy, równy około $20 \%$ PKB Pakistanu, obejmuje chińskie kredyty preferencyjne na trzy projekty autostradowe i międzynarodowy port lotniczy oraz dofinansowanie ze strony chińskich Exim Bank, China Development Bank i Industrial Commercial Bank of China. Wizję korytarza gospodarczego Chiny-Pakistan uzupełniają dwa projekty finansowane z AIIB: projekt rozbudowy elektrowni Pakistan Tarbela 557 i projekt pakistańskiej autostrady krajowej M-4 [de Jonge 2017, s. 1069-1070].

AIIB, podobnie jak inne tego typu instytucje, będzie miał wielopłaszczyznową strukturę zarządzania obejmującą prezesa, radę gubernatorów, radę dyrektorów i zarząd [AIIBa]. Dodatkowo kierownictwo jest wspomagane przez radę ekspertów międzynarodowych. Kompetencje poszczególnych ciał przedstawiają się następująco:

1. Prezes - kluczową kwestią dla funkcjonowania banku są zasady wyboru prezesa. Fakt, że prezesem Banku Światowego zawsze był Amerykanin, dyrektorem Międzynarodowego Funduszu Walutowego - Europejczyk, a gubernator ADB był z Japonii, wywoływał kontrowersje i pytania o przejrzystość procesu selekcji oraz bezstronność kierownictwa wyższego szczebla w wykonywaniu obowiązków. Artykuł 29 ust. 1 stanowi, że „Rada Gubernatorów, w drodze otwartego, przejrzystego i opartego na kompetencjach procesu, wybiera prezesa Banku absolutną większością głosów [...] Będzie on obywatelem regionalnego kraju członkowskiego". Prezes kieruje działalnością AIIB i odpowiada za jego pracę.

2. Rada gubernatorów - zgodnie ze statutem AIIB rada gubernatorów jest najwyższym organem decyzyjnym. Wszystkie uprawnienia co do funkcjonowania i działalności Banku należą do rady gubernatorów. Obecny zarząd gubernatorów składa się z 56 członków pochodzących z 55 krajów i jednego gubernatora z Hongkongu; od 17 czerwca 2017 r. Rada Gubernatorów przekazuje uprawnienia Zarządowi odpowiedzialnemu za bieżące funkcjonowanie AIIB.

3. Rada dyrektorów AIIB - aktualnie ma 12 członków. Artykuł 25 statutu wymaga, aby 9 z nich było wybieranych przez gubernatorów reprezentujących członków regionalnych, a 3 reprezentujących członków - spoza regionu. Każdy z nich reprezentuje kilku członków założycieli jako swój swoisty „okręg”. Rada dyrektorów niebędących rezydentami jest odpowiedzialna za zatwierdzanie strategii AIIB, rocznego planu i budżetu, ustalanie polityki, podejmowanie decyzji dotyczących operacji Banku oraz nadzorowanie bieżącego funkcjonowania AIIB. Artykuł 26 wymaga również, aby rada dyrektorów ustanowiła mechanizm nadzoru zgodnie z zasadami otwartości, przejrzystości, niezależności i odpowiedzialności.

4. Zarząd AIIB - kieruje nim prezes wybierany na pięcioletnią kadencję przez radę gubernatorów (zgodnie z artykułem 29 statutu). Prezesa wspomaga pięciu wiceprezesów, główny radca prawny i główny specjalista ds. zarządzania ryzykiem. 
5. Międzynarodowy Panel Doradczy (IAP) - składa się z globalnych ekspertów, którzy zapewniają kierownictwu AIIB porady i dokonują analiz i prognoz. IAP spotyka się z AIIB lub na wniosek prezydenta. Paneliści IAP są mianowani przez prezesa AIIB na dwuletnią kadencję. Otrzymują honorarium, ale nie otrzymują wynagrodzenia. AIIB pokrywa koszty związane z posiedzeniami panelu.

Prezes AIIB, Jin, przy różnych okazjach podkreślał, że podstawową wartością AIIB jest Lean, Clean and Green, co oznacza relatywnie niewielki, ale efektywny zespół zarządzający z wysoko wykwalifikowanym personelem. Sama instytucja ma być możliwie najbardziej „,czysta”, czyli wolna od korupcji, działająca z szacunkiem i świadomością problemów ochrony środowiska [Santos Lean 2015].

Zaprezentowane fakty wskazują, że Pekin i twórcy AIIB próbują korzystać z bogatego zasobu doświadczeń innych, dużych instytucji międzynarodowych. Ostatecznie jednak kluczowym czynnikiem podczas dokonywania prognoz względem AIIB jest to, czy nowy bank będzie skuteczny w perspektywie średnio- i długoterminowej jako instytucja finansująca i wspierająca modernizację infrastruktury. Chińczycy $\mathrm{i}$ ich partnerzy w AIIB postawili przed sobą ambitny cel, jakim jest wyciągnięcie wniosków, a nie tylko skopiowanie tzw. najlepszych praktyk. Celem jest raczej poprawa istniejących norm i przekroczenie obecnych standardów.

Chociaż AIIB przyciąga dużą liczbę krajów rozwijających się i rozwiniętych, nie ma gwarancji pełnego sukcesu w przyszłości. Jest wiele poważnych wyzwań dla młodej wielostronnej instytucji. Po pierwsze, mimo ambitnych planów AIIB nie ma wystarczająco środków, które mogłyby sfinansować wszystkie potrzeby infrastrukturalne w perspektywie najbliższych lat. Młodej instytucji brakuje doświadczenia, wiedzy i praktyki, które zapewniłyby efektywność i skuteczność działania. Problematyczne jest, na ile AIIB będzie w stanie pozyskać środki na międzynarodowych rynkach kapitałowych. Projekty infrastrukturalne nie są „,naturalnie” atrakcyjnymi inwestycjami ze względu na dużą niepewność i rozłożenie w czasie potencjalnych zysków. AIIB musi znaleźć sposoby poprawy rentowności swoich projektów skorygowanych o ryzyko. Nie ma pewności, czy AIIB może osiągnąć lepsze wyniki niż inne znacznie dojrzalsze instytucje rozwojowe. Wciąż są wątpliwości co do transparentności procedur oraz przestrzegania norm ochrony środowiska przy realizacji projektów przez AIIB. Problematyczne jest, na ile AIIB będzie narzędziem realizacji chińskiej polityki, w szczególności wobec doświadczeń i kontrowersji wokół chińskiej pomocy rozwojowej udzielanej przez Chiny państwom afrykańskim.

\section{Działalność inwestycyjna AIIB}

Proces pozyskiwania finansowania $\mathrm{w}$ ramach AIIB powinien być zgodny ze strategicznymi celami i z priorytetami instytucji, tj. zrównoważonym rozwojem, łącznością między krajami i mobilizacją prywatnego kapitału. Proces oceny finansowania projektów w ramach AIIB składa się z następujących stadiów [AIIBb]: 
1. Programowanie strategiczne (strategic programming) - AIIB analizuje propozycje projektów. Projekty spełniające wstępne kryteria są włączane do programu inwestycyjnego, który jest omawiany i zatwierdzany przez komitet wykonawczy (executive committee).

2. Identyfikacja projektu (project identification) - w ramach fazy identyfikacji projektu potencjalny kredytobiorca składa dokumentację dotyczącą proponowanego projektu. Dokumentacja ta może zawierać krótkie podsumowanie projektu i/lub wstępną analizę wykonalności. Po analizie otrzymanych informacji AIIB może zażądać przeprowadzenia dodatkowych analiz w celu dokładniejszej oceny proponowanego projektu. Dodatkowe badania mogą obejmować wizytę na miejscu w celu przeprowadzenia oceny faktycznej zasadności projektu i potencjalnych skutków społecznych, gospodarczych i środowiskowych. Mogą również obejmować dodatkowe analizy związane z oceną czynników technicznych, ekonomicznych, finansowych, społecznych, środowiskowych i zarządczych wpływających na potencjał i skutki finansowanego projektu. Na podstawie wstępnego przeglądu i dodatkowych badań AIIB współpracuje z potencjalnym kredytobiorcą w przygotowaniu dokumentów koncepcyjnych projektu, które zostaną wykorzystane w wewnętrznych obradach $i$ analizach.

3. Przygotowanie projektu (project preparation) - podczas tej fazy zespół projektowy AIIB i wyznaczone agencje ściśle współpracują przy przygotowaniu projektu. Ponadto zespół projektowy AIIB dokonuje wstępnej analizy dokumentacji projektu i podejmuje współpracę w celu usunięcia stwierdzonych braków. Po ocenie zespół AIIB przygotowuje dokument, który będzie zawierał cel oraz wpływ projektu, uzasadnienie, szacunkowe koszty, plan finansowania, harmonogram wdrożenia, ocenę ryzyka i inne ustalenia dotyczące projektu. Po wewnętrznej recenzji projekt jest finalizowany. Przygotowuje się projekty umów pożyczek i umów projektowych, które następnie są przekazywane dalej na potrzeby ostatecznych negocjacji i ustaleń.

4. Zatwierdzenie przez zarząd (board approval) - po negocjacjach z pożyczkobiorcą dokumentacja projektu jest przekazywana zarządowi AIIB. Po zatwierdzeniu przez zarząd przedstawiciel pożyczkobiorcy i wiceprezes AIIB oraz dyrektor ds. inwestycji podpisują umowy pożyczki i projektu zgodnie z uzgodnionym terminem. Dokumentacja projektu jest publikowana na stronie internetowej AIIB. Pożyczka zostaje udzielona po spełnieniu ustalonych w negocjacjach warunków.

5. Wdrażanie projektu (project implementation) - ten etap obejmuje:

- przygotowanie systemu zamówień, w tym wyboru wykonawców/dostawców;

- proces wdrożenia - obejmuje przede wszystkim utworzenie w pełni funkcjonalnych biur projektowych z wykwalifikowanym personelem, którego celem jest efektywne i skuteczne zarządzanie inwestycją; wyznaczone agencje wykonawcze i wdrożeniowe są odpowiedzialne za realizację projektu zgodnie z ustaleniami zawartymi w szczegółowej dokumentacji projektu.

Jednocześnie powołane Biuro Wdrażania Projektu Kredytobiorcy (Borrower's Project Implementation Office) jest odpowiedzialne za terminowe wdrożenie pro- 
jektu. W razie potrzeby pożyczkobiorca może zatrudnić konsultantów w zakresie szczegółowego projektowania, przygotowywania dokumentów przetargowych i wyłaniania wykonawców i dostawców czy przeprowadzania specjalistycznych szkoleń. Zespół projektowy AIIB pozostaje w pełni zaangażowany w trakcie realizacji projektu od jego rozpoczęcia do ukończenia. Monitorowanie realizacji projektu przez AIIB nie ogranicza się tylko do okresowego przeprowadzania misji kontrolnych, zwykle odbywających się dwa razy w roku, ale również polega na świadczeniu usług doradczych w czasie realizacji projektu. Ponadto Biuro Wdrażania Projektu Kredytobiorcy przygotowuje miesięczne raporty z postępów, w tym raporty z zarządzania środowiskowego i społecznego. Raporty ukazują dokonany postęp, kwestie i problemy związane z umowami lub zarządzaniem projektem (jeśli istnieją) i podejmowane działania. AIIB organizuje także warsztaty poświęcone zamówieniom, planom wydatkowania i planom związanym z kwestiami środowiskowymi i przesiedleńczymi w celu wsparcia instytucji wdrażających.

6. Zakończenie i ewaluacja projektu (project completion and evaluation) - kredytodawca wraz z wyznaczonym zespołem AIIB dostarcza raport o zakończeniu projektu w ciągu 6-12 miesięcy po zakończeniu projektu. Zespół przygotowuje raport koncentrujący się wokół osiągniętych rezultatów i wyników oraz stopnia osiągnięcia celów w porównaniu z zamierzeniami, a także główne wnioski wyciągnięte na potrzeby przyszłych projektów. Po zatwierdzeniu przez wiceprezesa i dyrektora ds. inwestycji w AIIB raport podsumowujący projekt jest przedkładany zarządowi do wiadomości.

Ogółem od czasu powstania AIIB uruchomiono 31 wniosków o finansowanie lub współfinansowanie projektów rozwojowych - w 2016 r. było to 8 wniosków, w 2017 r. - 15, a w 2018 r. - 8. Ponadto kolejnych 25 wniosków jest w fazie uzgadniania i projektowania. Wszystkie wnioski powinny być realizowane w ramach następujących sektorów: energetyka, telekomunikacja, transport, rozwój miast, dostęp do wody. Dopuszcza się jednak finansowanie w ramach innych sektorów, o ile są one zgodne z wizją i celem AIIB, oraz projekty o charakterze wielosektorowym (rys. 2).

Politykę inwestycyjną AIIB cechuje relatywnie wysoki poziom ostrożności - zagregowany udział wkładu banku w stosunku do całościowej wartości inwestycji wynosi $23 \%$. Zachowawcza polityka oznacza nie tylko znaczne ograniczenie ryzyka dla samego banku, ale jednocześnie stymuluje poszczególne kraje będące beneficjentami do poszukiwania alternatywnych źródeł finansowania, również ze środków krajowych (por. rys. 3).

Większość inwestycji jest zlokalizowana na terenie Azji, w mniejszym stopniu na Kaukazie. Największymi beneficjentami są Indie, które uzyskały finansowanie na osiem projektów oraz złożyły wnioski na cztery kolejne. Wybija się również Bangladesz, który uzyskał finansowanie na trzy projekty i kolejne cztery są procedowane, podobnie jest w przypadku Pakistanu, który ogółem złożył wnioski na sześć projektów (dwa zaakceptowane, cztery procedowane). Ciekawym przypadkiem jest Indonezja, która choć ma zaakceptowany tylko jeden wniosek, to procedowane są cztery 


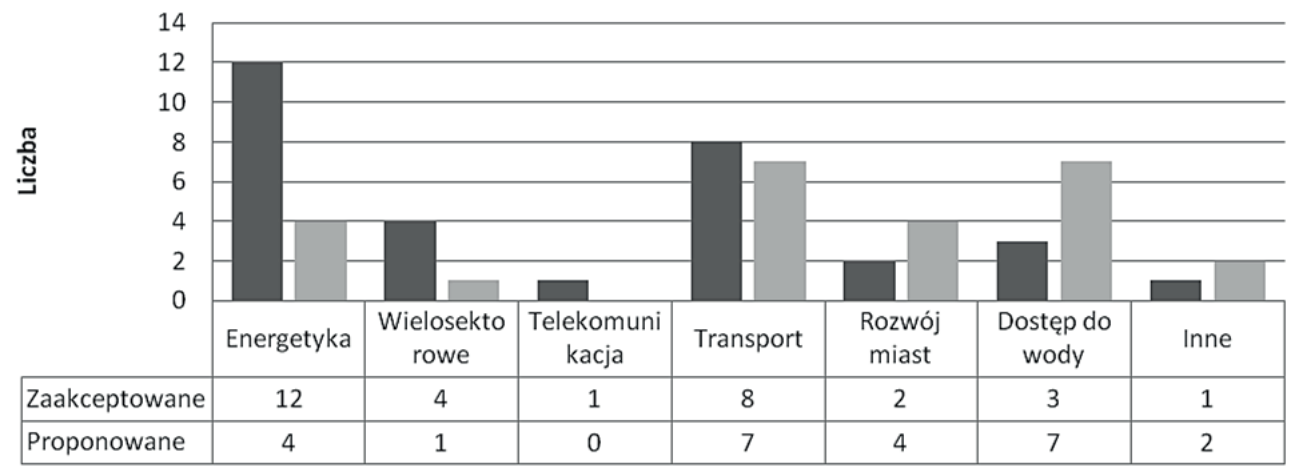

Sektor

$\square$ Zaakceptowane $\square$ Proponowane

Rys. 2. Projekty zaakceptowane i proponowane w ramach działalności inwestycyjnej AIIB w podziale na sektory

Źródło: opracowanie własne na podstawie [AIIB 2018a; AIIB 2018b].

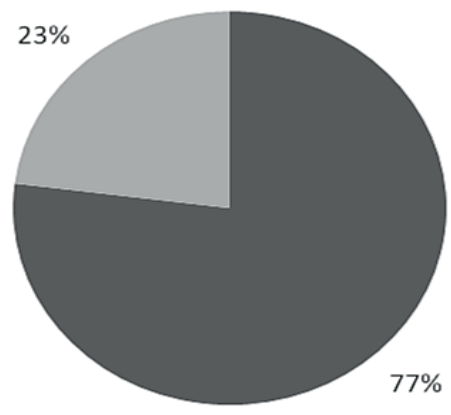

口Udział finansowania AllB $\quad$ Udział finansowania własnego

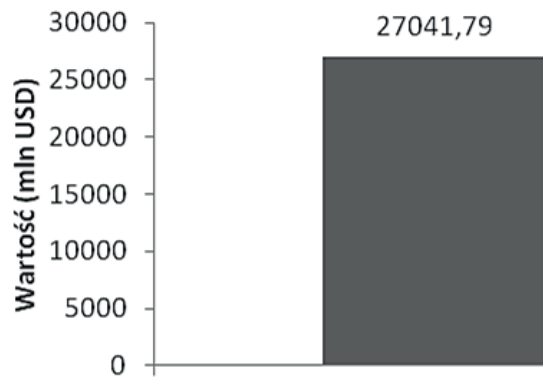

Całość
6197,6

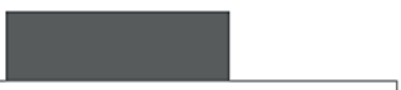

Wkład AllB

Rys. 3. Wartość wkładu finansowego AIIB w zaakceptowane projekty inwestycyjne w mln dolarów ogółem oraz jako udział w ogólnej wartości projektów w latach 2016-2018

Źródło: opracowanie własne na podstawie [AIIB 2018a; AIIB 2018b]. 
kolejne, oraz Sri Lanka, która złożyła wnioski na pięć projektów. Inne państwa składały wnioski średnio na jeden-dwa projekty (m.in. Azerbejdżan, Uzbekistan, Gruzja, Myanmar, Laos, Oman, Egipt, Filipiny czy Turcja).

Polityka względem państw przynajmniej do pewnego stopnia pokazuje polityczny aspekt działalności AIIB. Wyraźnie wybija się region Azji Południowej, ze szczególnym uwzględnieniem Pakistanu, Bangladeszu i Sri Lanki, czyli państw strategicznych z punktu widzenia Chin w kontekście rywalizacji o dominację w Azji. Nie bez znaczenia pozostaje również bliski sojusz Indii i USA, które łączą strategiczne interesy.

Analiza statystyczna wielkości pokazuje relatywnie wysoki poziom zróżnicowania poziomu finansowania projektów wspieranych przez AIIB - od minimalnego do większościowego. Również w wartościach bezwzględnych takie zróżnicowanie istnieje. Potwierdzają to wysoki poziom odchylenia standardowego oraz istotne zróżnicowanie średniej względem mediany (tab. 2).

Tabela 2. Wybrane statystyki opisowe wartości bezwzględnych finansowania projektów przez AIIB w mln dolarów i jako udziały (w \%) w całości projektu

\begin{tabular}{|l|c|c|}
\hline \multicolumn{1}{|c|}{ Statystyka } & $\begin{array}{c}\text { Wartości bezwzględne } \\
\text { (mln USD) }\end{array}$ & Wartości względne (\%) \\
\hline Średnia & 409,12 & 0,5411 \\
\hline Mediana & 193,2 & 0,0478 \\
\hline Odchylenie standardowe & 445,93 & 0,5000 \\
\hline Wariancja próbki & 198856,79 & 0,2343 \\
\hline Minimum & 40 & 0,0549 \\
\hline Maksimum & 1245 & 0,8422 \\
\hline
\end{tabular}

Źródło: opracowanie własne na podstawie [AIIB 2018a; AIIB 2018b].

Podsumowując, należy stwierdzić, że od chwili swojego powstania AIIB prowadzi aktywną politykę inwestycyjną w zakresie szeroko pojętej infrastruktury - przede wszystkim energetyki i transportu, co współgra z chińską strategią rozwoju połączeń i komunikacji w ramach inicjatywy Jednego Pasa, Jednej Drogi. Działalność jest prowadzona ostrożnie i bezpiecznie - średni poziom finansowania nie przekracza $35 \%$ całości inwestycji, niemniej występuje wysoki poziom zmienności wartości finansowania inwestycji - od minimalnego wkładu do praktycznie całościowego. Trudno jednoznacznie wnioskować na temat dalszego rozwoju działalności inwestycyjnej - ogranicza za krótki czas i za mała próba, co oznacza konieczność dalszych badań. 


\section{Zakończenie}

Azjatycki Bank Inwestycji Infrastrukturalnych od momentu powstania wzbudza zainteresowani zarówno polityków, jak i badaczy i analityków, w szczególności w rejonie Azji, którzy widzą w nowej instytucji potencjalnego partnera do współfinansowania projektów infrastrukturalnych. Mimo krótkiego okresu działalności AIIB szybko stał się instytucją globalną, zrzeszającą dużą liczbę państw ze wszystkich kontynentów, w tym członków UE i OECD.

Wraz z początkiem swojej działalności AIIB zaczął prowadzić działalność wspierania i wspólfinansowania inwestycji w państwach regionu, co stanowi główny cel jego działalności. Dotychczasową politykę inwestycyjną należy ocenić jako ostrożną i umiarkowaną. Zagregowana wartość współfinansowania AIIB w sumie wartości projektów wynosi 23\%. Jednocześnie średni poziom finansowania zazwyczaj nie przekracza $35 \%$ całości inwestycji, przy wysokim poziomie zmienności wartości finansowania inwestycji - od minimalnego wkładu do praktycznie całościowego.

Ze względu na krótki czas działalności oraz relatywnie niewielką liczbę finansowanych projektów konieczne są dalsze badania i analizy działalności inwestycyjnej AIIB, również w porównaniu z innymi globalnymi instytucjami finansowymi.

\section{Literatura}

ADB, 2018, Meeting Asia's Infrastructure Needs, https://www.adb.org/publications/asia-infrastructure-needs (13.11.2018).

AIIBa, Articles of Agreement, https://www.aiib.org/en/about-aiib/basic-documents/_download/articles-of-agreement/basic_document_english-bank_articles_of_agreement.pdf (14.11.2018).

AIIBb, Project Process, https://www.aiib.org/en/projects/process/index.html (22.11.2018).

AIIB, 2017, AIIB Welcomes New Prospective Members. Bank Approves 13 New Applicants; Expands Membership to 70, https://www.aiib.org/en/news-events/news/2017/20170323_001.html (15.11.2018).

AIIB, 2018a, Members and Prospective Members of the Bank, https://www.aiib.org/en/about-aiib/governance/members-of-bank/index.html (15.11.2018).

AIIB 2018b, Projects Approved, https://www.aiib.org/en/projects/approved/index.html (22.11.2018).

AIIB, 2018c, Projects Proposed, https://www.aiib.org/en/projects/proposed/index.html (22.11.2018).

Callaghan M., Hubbard P., 2016, The Asian Infrastructure Investment Bank: Multilateralism on the Silk Road, China Economic Journal, vol. 9, iss. 2, s. 121.

Chin G.T., 2016, Asian Infrastructure Investment Bank: Governance innovation and prospects, Global Governance, 22, s. 13.

Czaputowicz J., 2007, Teorie stosunków międzynarodowych. Krytyka i systematyzacja, Wydawnictwo Naukowe PWN, Warszawa, s. 187.

De Jonge A., 2017, Perspectives on the emerging role of the Asian Infrastructure Investment Bank, International Affairs, vol. e 93, iss. 5, s. 1061-1084.

EIB, 2016, EIB Issues First Green Bond of 2016, http://www.eib.org/investor_relations/press/2016/fi2016-002-eib-issues-first-Green-Bond-of-2016.htm?lang=en (15.11.2018). 
Etzioni A., 2016, The Asian Infrastructure Investment Bank: A case study of multifaceted containment, Asian Perspective 40, s. 174.

International Bank for Reconstruction and Development Subscriptions and Voting power of Member Countries, http://siteresources.worldbank.org/BODINT/Resources/278027-1215524804501/ IBRDCountryVotingTable.pdf.

Kalwasiński M., 2017, Azjatycki Bank Inwestycji Infrastrukturalnych - geneza i cele, Ekonomia XXI Wieku, nr 1 (13), s. 23-39.

Liu Z., Umehara N., 2017, Asian Infrastructure Investment Bank: As a new comer in the society of Multilateral Development Banks, Newsletter of Institute for International Monetary Affairs in Tokyo, no. 7, s. 9.

Piasecki R., 2008, Ekonomia rozwoju wobec problemów nędzy i nierówności społecznych na świecie, Annales. Etyka w Życiu Gospodarczym, vol. 11, nr 1, s. 230-231.

Santos Lean A., 2015, Deviating from the Norm: AIIB Moves Away from Country Strategies, http:// www.devex.com/news/deviating -from -norm-aiib-moves-away-from-country-strategies- 86544 (20.11.2018).

World Bank, 2016, Statement by Multilateral Development Banks: Delivering on the 2030 Agenda, http:/www.worldbank.org/en/news/press-release/2016/10/09/delivering-on-the-2030-agenda-statement (15.11.2018).

Zaremba M., 2017, Nowy Jedwabny Szlak jako instrument chińskiej ekspansji we wspótczesnej gospodarce światowej, Zeszyty Naukowe Polskiego Towarzystwa Ekonomicznego w Zielonej Górze, nr 6, s. 198-206. 